\title{
The Role of Technical Visits in Learning and Institutionalizing External Control Practices
}

\author{
Felício Ribas Torres ${ }^{\dagger}$ \\ Brazil's Federal Audit Tribunal \\ Tomás de Aquino Guimarães * \\ Universidade de Brasília
}

\begin{abstract}
This article describes the process of acquiring external knowledge through technical visits and its role in institutionalizing the external control practices of the Brazilian Federal Audit Tribunal. Technical field visits made by the entity from 1998 to 2004 are identified and described. The theoretical framework is based on studies of organizational learning and the institutional approach, with focus on institutional isomorphism. The study takes a qualitative approach, based on data collected in 2006, in two stages. In the first, internal documents related to technical visits were analysed and in the second, 18 semi-structured interviews were conducted with people involved in those visits. Content analyses was the principal data analysis technique. The main results are that the technical visits, associated with conversion of the knowledge acquired into practice, have affected the institutionalization of the Tribunal's external control practices, in an isomorphic context.
\end{abstract}

Keywords: learning processes; institutionalization; isomorphism; technical visits.

Received in 01/28/2008; revised in 04/02/2008; accept in 03/20/2008.

Corresponding authors:

f External Control Analist in Brazil's Federal Audit Tribunal

Address: SQSW 301, H Bloc, Room 106, Southeast,

Brasília/DF, Brazil, CEP 70673-108

Phone: + $55613253-7222$

e-mail:feliciort@gmail.com
+ Associate Professor in University of Brasília Address: SQN 116, I Bloc, Room. 305, BrasíliaDF, Brazil, CEP 70773-090

Phone: +55 $613307-2545$

e-mail:tomas@unb.br

Editor's note: This paper was accepted by Alexsandro Broedel Lopes. 


\section{INTRODUCTION}

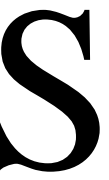

tudies of processes of organizational adaptation as a strategy to achieve greater efficiency have been indicated as important by experts on organizations (GINSBERG and BUCHHOLTZ, 1990). One of the theories involving adaptation of organizations to environmental changes is institutional theory. This approach seeks to explain why institutions arise, evolve or become stable, investigating how standards assume the condition of values and acquire legitimacy in social structures. According to Mendonça and Amantinode-Andrade (2003), institutional perspective can be characterized as a symbolic-interpretive approach to organizational reality, presenting a predominantly subjective epistemological position in which the construction of social reality stands out.

The institutional approach, when applied to organizational studies, looks at homogenization of practices, procedures and structures by organizations. This phenomenon is called institutional isomorphism (FOUNTAIN, 2001; SCOTT, 2001). The reproduction of processes, practices and routines considered successful in other organizations, in an attempt to improve performance, is common in organizations both in the private and public sector.

Organizational learning, one of the theoretical foci of this article, is a field that studies knowledge within organizations through their progressive adaptations of new ideas and exchange of experiences, to instrumentalize actions and practices that can meet the needs of a particular environment. Although this concept has arisen in the context of management studies, according to Machado-da-Silva and Guarido Filho (2001), it is possible to bring it to bear from various perspectives, especially from the standpoint of institutional theory.

The institutional approach and organizational learning concept can be analyzed from a cultural-cognitive perspective (EASTERBY-SMITH and ARAUJO, 2001; GUIMARÃES, 2004), which denotes the possible existence of a relationship between the two concepts. In this sense, this article aims to contribute to understand this possible relation, employing as a locus of research the Federal Audit Tribunal (Tribunal de Contas da União - TCU) as an object to study the institutionalization of external control practices. The objective, then, is to identify how this phenomenon is related to learning processes and the way of acquiring external knowledge, more specifically, the wisdom acquired through technical visits to counterpart organizations.

There is evidence that implementation and development of external control activities can occur under the optic or institutional isomorphism. A common practice is to hold meetings among audit and control entities of various countries, at which experiences and ideas are shared and discussed. However, it is not known to what degree learning processes contribute toward institutionalization of these activities. The present study seeks to contribute in this area, by investigating the use of technical visits under the prisms of organizational learning and institutional theory.

\section{ORGANIZATIONAL LEARNING}

Cabral (2000, p.228) suggests that learning can make an organization more efficient not only by its effect on individuals, but also on the organization as a whole. According to Argyris and Schön (1996), the term learning can be separated into two concepts, "what to learn" and "how to learn". The first refers to the accumulation of information, in the form of knowledge and skills, and the second refers to the means or process of learning. The concept of learning is based on the capacity of the human being to acquire and retain information. According to Guimarães (2004), the development and perpetuation of laws, customs and 
social institutions results from the human capacity to learn and transfer knowledge to others. Thus, individual is the agent of learning.

According to Easterby-Smith and Araújo (2001, p.15), the field of organizational learning has "attracted the attention of academics from various disciplines that so far have shown little interest in learning processes." One of the discussions in this field involves the role of individual learning in organizational learning (HUYSMAN, 2001). One line of thought argues that it is individual who acts and learns within organizational structure, being the primary learning component in companies, creating means for organizational transformation (DODGSON, 1993). On the other hand, Argyris and Schön (1996) report that if organizations are collectivities formed by individuals, organizations learn when their members - or part of them - learn.

Fiol and Lyles (1985) observe further that organizations develop learning systems that are manifested through rules, mental maps, stories, behaviors and values. These cognitive systems and memories are developed and shared bv members of an organization, which makes organizational learning different from the sum of the individual learning of the members. This same reasoning leads Argyris and Schön (1996, p.7) to state that "there are situations in which an organization seems to know far more than its individual members."

The verb "seems" used by Argyris and Schön (1996) well depicts the opinion of Bastos et al. (2004), when they argue that organizational learning is a metaphor that permits attributing human characteristics to organizations. In this sense, an organization does not have the power to learn, because it is not a human being. This perspective corroborates the opinion of Doving (1996), who stresses that organizational learning can only be found in the actions of organizational actors, that is, individuals. It should also be mentioned that there is a belief that an inherent consequence of learning is the production of beneficial results for the organization, such as greater adaptation to change, increased efficiency, improved decision making and reduced organizational errors (BASTOS et al., 2004). This positive vision of learning, however, disregards the fact that an organization can also learn the wrong things (GUIMARÃES, 2004).

Notwithstanding this discussion among the different theoretical currents regarding the subject of learning, the complexity of the phenomenon suggests that the fullest conception is that organizational learning is a multilevel phenomenon, that is, it acts at the individual, group and organizational levels (CROSSAN et al., 1999). According to Pantoja and Borges-Andrade (2004), organizations are multilevel systems, which integrate work processes at the individual, group and organizational levels and learning is a psychological process that occurs only at the individual level. To understand how learning that occurs at the individual level can produce effects at other levels, the concept of transfer is used, understood as the occurrence of changes in individuals in situations distinct from those in which the acquisition of knowledge occurs.

A model to understand the dynamic of learning in organizations was proposed by Crossan et al. (1999) and subsequently refined by Zietsma et al. (2002). This model identifies six steps of integrated learning, analyzed at three levels (individuals, groups and organizations). These steps can be summarized as follows:

a) intuition - recognition by individuals of new patterns or possibilities based on previous experiences, images and metaphors;

b) attending - active process of searching for information and knowledge of the environment;

c) interpretation - what occurs when individuals share their intuitions with group, through conversations, metaphors and images; during the interpretation step, existing cognitive maps are reformulated and new maps of learning domains are developed; 
d) experimentation - what occurs when individuals and groups conduct experiments and results of their actions add substance to their cognitive interpretations;

e) integration - collective actions of group, which coherently share interpretations or comprehensions in express cognitive maps through language, in coordinated form;

f) institutionalization -introduction of new actions and interpretations in routines, rules, information systems, strategy and structure of the organization.

These steps of the learning process and the different levels of analysis at which they occur are represented in Figure 1.

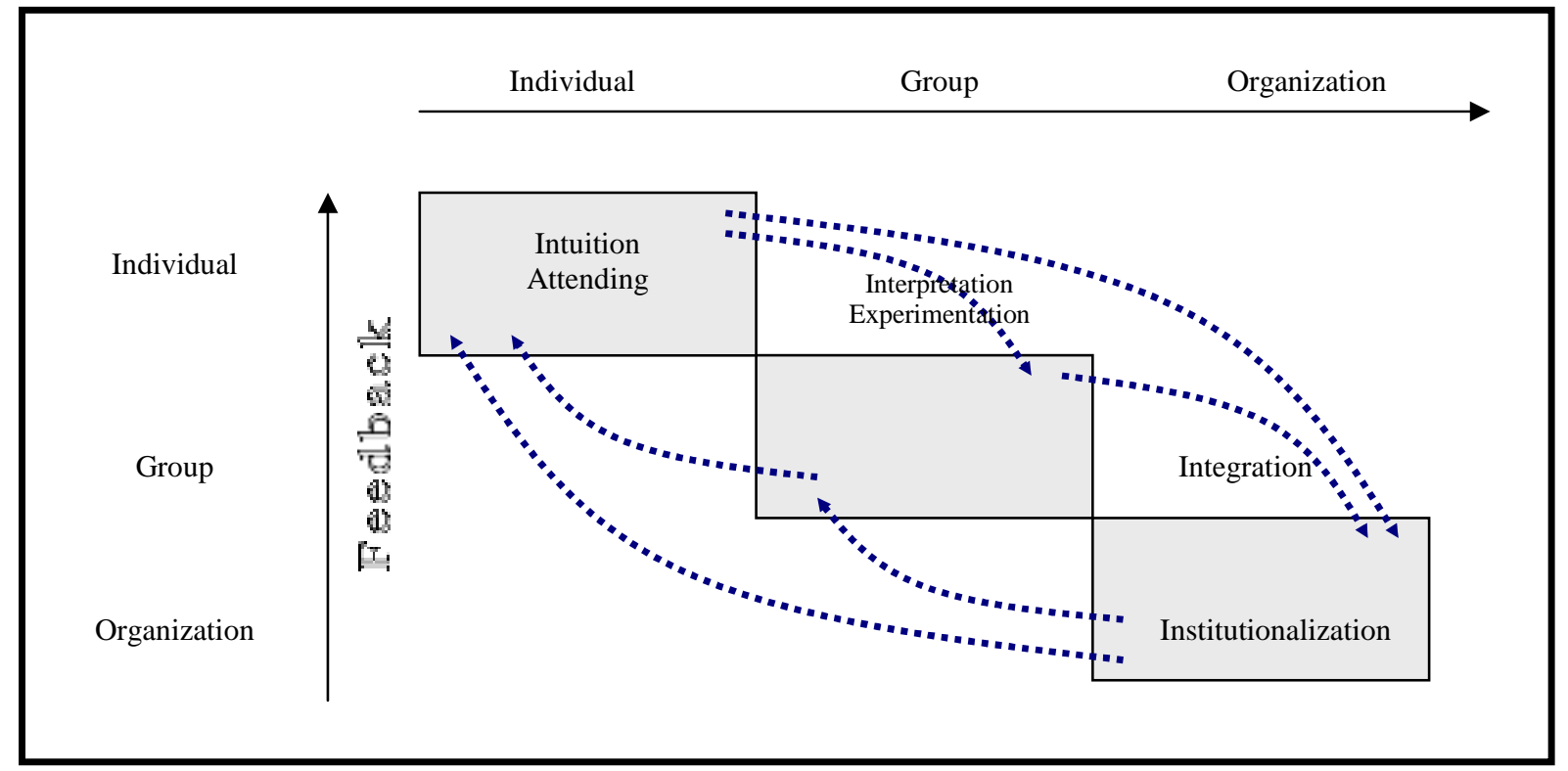

Figure 1. Learning at different organizational levels

Source: Zietsma, et al. (2002, p. S63 )

According to this model, the steps of intuition and attending occur at individual level; interpretation occurs both at individual and group level; experimentation occurs only at group level; integration occurs at group and organizational level; and institutionalization occurs at organizational level (CROSSAN et al., 1999; ZIETSMA et al., 2001). These steps include another two macro-steps in the process of learning in organizations, called feedforward and feedback, depending on the direction of the flow between the levels at which they take place. Feedforward means transfer of knowledge and skills from individuals and groups to organization, while feedback reflects the process of appropriation and use by organization of what was learned and transformed into institutionalized routines and practices and how this process affects individuals and groups in carrying out the organization's activities (CROSSAN et al., 1999).

Figueiredo (2003) presents an approach to how organizational learning takes place. The author argues that learning in organizations consists of the various processes by which individuals, and thus organizations, acquire technical skills and knowledge. According to Choo (2003), the knowledge gaps in organizations are filled in by different means, whether by acquiring knowledge from outside, locating the specialization within the organization itself, learning or developing the necessary capacities. Figueiredo (2003), using the model formulated by Nonaka and Takeuchi (1997), classifies learning processes into four types, in which the first two constitute mechanisms of acquiring knowledge, while the last two are mechanisms for knowledge conversion: 
a) processes of acquiring external knowledge: processes in which individuals acquire knowledge from outside their organization, by importing external wisdom, technical visits, benchmarking, technical assistance, training sessions or presentations given by specialists;

b) processes of acquiring internal knowledge: processes by which individuals acquire tacit knowledge by exercising different activities within organization, which consist of performing routine tasks and of perfecting processes by systematic experimentation in various organizational units;

c) processes of socializing knowledge: formal and informal processes by which individuals share their tacit wisdom, transmitting knowledge to other individuals or groups of individuals;

d) processes of codifying knowledge: processes by which tacit knowledge is expressed in explicit concepts, making it easier to assimilate; this category covers processes such as standardization of production methods, documentation and internal seminars.

Because this work proposes to study the contributions of process of acquiring external knowledge, through technical visits, for institutionalization of external control practices, it is necessary now to discuss institutional theory, with emphasis on isomorphism.

\section{INSTITUTIONAL THEORY}

Scott (1998) stresses that institutional approach contains contributions from various fields, among them economics, political science and sociology. In the same line, Machado-daSilva and Gonçalves (1998, p. 220) affirm that the bases of institutional theory, as applied today in the study of organizations, is composed of the:

result of the convergence of influences from theoretical systems originating mainly from political science, sociology and economics, which seek to incorporate in their propositions the idea of institutions and standards of behavior, rules, beliefs and assumptions in which individuals, groups and organizations are immersed.

Two intrinsic concepts to institutional approach are those of institution and institutionalization. However, Tolbert and Zucker (1999) argue that there is still little consensus on the definition of these key concepts. Jepperson (1991) defines institution as an organized and established procedure as a normative system, consisting of self-replicating and socially constructed routines. The author further affirms that institutionalization denotes the process that causes an order or social standard to attain a determined state or property that can be considered an institution. This interpretation corroborates the argumentation of Selznick (1971, p. 14), who defines institutionalization, from an organizational standpoint, as a process, i.e., something that happens to an organization with the passage of time, reflecting its particular history, people who have worked in it, groups and various interests that created it, and the way it has adapted to its environment.

Esman and Blaise (1966) view institutionalization as a phenomenon of social change. These authors propose an analytical model of institutionalization process, in an organizational perspective, containing internal and external variables, according to Chart 1. 


\begin{tabular}{l|l}
\hline \multicolumn{2}{c}{ Process of Institutionalization } \\
\hline Leadership & $\begin{array}{l}\text { Group of people who are actively engaged in formulating the institution's } \\
\text { programmatic doctrine and who direct its operations and relations with the } \\
\text { environment. Is directly related to political effort to implement or maintain an } \\
\text { institution; }\end{array}$ \\
\hline Doctrine & $\begin{array}{l}\text { Values, objectives and methods present in an institution that consolidate its } \\
\text { social action; }\end{array}$ \\
\hline Program & Plans that define guidelines for action or standards of behavior of institutions; \\
\hline Resources & $\begin{array}{l}\text { Financial, physical, technological, informational and human elements utilized by } \\
\text { the institution; }\end{array}$ \\
\hline Internal Structure & $\begin{array}{l}\text { Structure and processes agreed for the operation and maintenance of the } \\
\text { institution. }\end{array}$ \\
\hline \multicolumn{1}{c}{ External Variables } \\
\hline Links & $\begin{array}{l}\text { Relationships of interdependence between an institution and other relevant } \\
\text { segments of society; }\end{array}$ \\
\hline Transactions & $\begin{array}{l}\text { Exchanges and relations with a limited number of organizations for the purpose } \\
\text { of gaining support, overcoming resistance, exchanging resources, structuring the } \\
\text { environment and transferring standards and values. }\end{array}$ \\
\hline
\end{tabular}

Chart 1: Internal and external variables in the institutionalization process

Source: Adapted from Esman and Blaise (1966).

According to Scott and Meyer (1992), changes and pressures from environment act to build different organizational fields to produce, with varying degrees of intensity, the phenomenon of institutional isomorphism. This term is defined by DiMaggio and Powell (1983, p.149) as "a constraining process that forces one unit in a population to resemble other units that face the same set of environmental conditions." Indeed, in the organizational field, isomorphism is the result of competitive pressures that force organizations to adopt more suitable forms for their survival (HANNAN; FREEMAN, 1977). Therefore, isomorphism can be understood as the search for legitimacy for action by means of the homogeneity of structures, processes and actions within the ambit of organizations.

DiMaggio and Powel (1991) suggest that the process of isomorphism develops through three mechanisms: coercive, normative and mimetic. The coercive mechanism occurs when organizations are subjected to outside pressures, either formal or informal, from other organizations with which they have a relationship of dependence or because of the cultural expectations of the society in which the organization is inserted. An example of this isomorphic mechanism is the action of the government on organizations, through laws, rules and requirements. The normative mechanism originates from the establishment of standards by professional organizations, with the intent of providing a cognitive basis and giving legitimacy to the activities carried out by them. Universities and professional associations are two important sources of isomorphism from this perspective. Finally, mimetic isomorphism occurs because of uncertainty that afflicts organizations, making them search, in other organizations, for frameworks and models that can be reproduced (copied). In perceiving the success of other organizations involved in the same activities, organizations tend to behave mimetically (imitation), a process that explains the existence of fads and trends in the business world.

\section{METHODOLOGY}

This study, carried out in 2006, has a qualitative nature, which according to Richardson (1999), can be characterized as an attempt to gain a detailed understanding of the 
situational meanings and characteristics observed in documents and through interviews. The level of analysis is structural (Scott, 1998), because the focus is on the institutionalization in a determined organization, by presenting a cross section with a longitudinal perspective (VIEIRA, 2004).

Data referring to the knowledge acquired by technical visits was gathered with focus on external control practices, made by the technical staff of Brazil's Federal Audit Tribunal (Tribunal de Contas da União - TCU) to its counterpart entities in other countries in the period from 1998 to 2004. The time frame of the study is based on identification of a pronounced concentration of technical visits in that period. The methodology is the case study, defined by Yin (2001, p. 32) as "an empirical inquiry that investigates a contemporary phenomenon within its real-life context, especially when the boundaries between phenomenon and context are not clearly evident."

Documental research was undertaken by consulting internal bulletins, newsletters and other periodicals and information systems of the TCU, edited on the period from 1998 to 2004. The information gathered in this step was summarized into analytical charts. Eighteen semi-structured interviews with the use of a script prepared based on the theoretical framework were also undertaken. The interviewees were chosen according to the information obtained from the documents and represent groups of professional staff and directors of the Tribunal directly involved in formulating its policies, scheduling and realizing technical visits and implementing the routines resulting from these visits. The interviews were transcribed and analyzed seeking through convergences, divergences and emerging questions, to compare and contrast the findings with the theoretical framework. Content analysis techniques in assessing both the documents and interview responses were used.

To deepen the analysis of the interviews, the Atlas.TI software (version 5.0) was utilized, which helped to identify explanatory patterns in the study. Each variable considering first the quantification of the codes composing it and then the qualitative content of the segments, seeking when possible to identify relationship networks, which we recorded in diagrams was analyzed.

Technical visits were examined as a process of acquiring external knowledge, and the processes of converting knowledge from the individual or group to the organizational level (socialization and codification) was also analyzed, using the classification and variables proposed by Figueiredo (2003).

External control practices learned through technical visits were analyzed supported by the variables Program, Links and Resources / Structure proposed by Esman and Blaise (1966). The existence of institutional isomorphism was also assessed utilizing the typology presented by DiMaggio and Powel (1991), considering the motivation behind the technical visit for analysis of the primordial isomorphism type.

\section{RESULTS}

\subsection{Technical Visits}

Twenty technical visits were made by the TCU to other peer organizations between 1998 and 2004 (Chart 2) whose objective was to learn about external control activities. These visits were predominantly to the United Kingdom's National Audit Office (NAO) and Canada's Office of the Auditor General (OAG) (50\% of the total). This concentration was due largely to the existence of technical cooperation agreements between the TCU and those organizations. Another relevant aspect regards the model of organization visited. Although the 
TCU is structured as a court, only five of the twenty visits were made to an organization having this structure.

\begin{tabular}{|c|c|c|c|c|c|c|c|c|c|}
\hline Organization & Model & 1998 & 1999 & 2000 & 2001 & 2002 & 2003 & 2004 & Total \\
\hline $\begin{array}{l}\text { National Audit Office } \\
\text { (NAO) - United } \\
\text { Kingdom }\end{array}$ & Comptroller & & 1 & 2 & 1 & 1 & 1 & & 6 \\
\hline $\begin{array}{l}\text { Government } \\
\text { Accountability Office }(*) \\
(\mathrm{GAO}) \text { - United States }\end{array}$ & Comptroller & & & & & & & 1 & 1 \\
\hline $\begin{array}{l}\text { Tribunal de Contas - } \\
\text { Portugal }\end{array}$ & Tribunal & 1 & & & & & & & 1 \\
\hline $\begin{array}{l}\text { Norwegian: } \\
\text { Riksrevisjonen- Norway }\end{array}$ & Comptroller & 1 & & & & & & & 1 \\
\hline $\begin{array}{l}\text { Tribunal de Cuentas } \\
\text { Español - Spain }\end{array}$ & Tribunal & & & & & & & 1 & 1 \\
\hline Corte dei Conti- Italy & Tribunal & & & & & & & 1 & 1 \\
\hline $\begin{array}{l}\text { Cour des Comptes- } \\
\text { France }\end{array}$ & Tribunal & & & & & & & 1 & 1 \\
\hline $\begin{array}{l}\text { Court of Audit of } \\
\text { Belgium - Belgium }\end{array}$ & Tribunal & & & & & & & 1 & 1 \\
\hline $\begin{array}{l}\text { Algemene Rekenkamer - } \\
\text { Holland }\end{array}$ & Comptroller & & & & & & & 1 & 1 \\
\hline $\begin{array}{l}\text { Bundesrechnungshof-- } \\
\text { Germany }\end{array}$ & Comptroller & & & & & & & 1 & 1 \\
\hline $\begin{array}{l}\text { Australian National } \\
\text { Audit Office (ANAO) - } \\
\text { Australia }\end{array}$ & Comptroller & & & & & & & 1 & 1 \\
\hline $\begin{array}{l}\text { Office of the Auditor } \\
\text { General (OAG) - } \\
\text { Canada }\end{array}$ & Comptroller & & & & 1 & 1 & 1 & 1 & 4 \\
\hline Total & - & 2 & 1 & 2 & 2 & 2 & 2 & 9 & 20 \\
\hline
\end{tabular}

Chart 2: Organizations visited by technical staff and directors of the TCU

Source: Research data.

The main themes stressed in the visits were: a) operational auditing; b) oversight methods, with focus on combating corruption; c) risk analysis; and d) advanced auditing practices. This point is relevant for the analysis of the institutionalization of external control practices, which was the purpose of the visits.

In analyzing these visits, frequency, functioning and interaction variables proposed by Figueiredo (2003) were used. Regarding the frequency variable, this mechanism of acquiring knowledge can be classified as ongoing, since the planning of a visit generally occurred at the same time as another was occurring or while the knowledge gained from it was being disseminated. It is important to stress that the fact that the majority of the visits were part of TCU corporate projects contributed to the continuing use of this method of obtaining knowhow.

Regarding functioning, the signing of cooperative agreements with the general audit entities of the United Kingdom and Canada strongly influenced the structure of the entire process. Functioning was considered adequate because of the existence of clear criteria to choose the participants, broad internal disclosure of the selective processes, previously defined objectives and an adequately defined script for the visits. A strong interaction with 
other learning processes it is important to be stressed, since besides the codification of the knowledge in reports, the suggestions were the subject matter of experimentation and internal discussion, and the participants submitted their reports at seminars and served as instructors in internal training sessions within the TCU.

\subsection{Knowledge Converstion Processes (there are many 'regardings' in this section)}

In this topic the processes of converging knowledge are stressed, which according to Figueiredo (2003), are divided into processes of codifying and socializing knowledge. To analyze these processes the variables proposed by that author: variety and interaction were used.

Among the processes of codifying knowledge, the mechanisms that stood out were the preparation of reports on the technical visits and the formulation of norms and manuals.

Regarding the technical visit reports, they were prepared aiming to describe, analyze and

recommend techniques or procedures that could be adopted by the TCU. All of the visits

except one made in the period studied led to the publication and dissemination of reports in internal bulletins, and were also made available on the Tribunal's intranet. The exception was the visit to Norway in 1998, for which no report was found, a fact confirmed in the interviews.

Regarding rules, in 2000 the TCU created the Secretariat of Oversight and Evaluation of Government Programs (Secretaria de Fiscalização e Avaliação de Programas de Governo) and transformed the Office to Coordinate Oversight (Coordenação de Fiscalização) into the Adjunct Secretariat of Oversight (Secretaria Adjunta de Fiscalização). These structural changes in the Tribunal took place because of the new activities that were implemented due to the recommendations contained in the reports of technical visits. Specifically regarding the visits focused on operational auditing, in 2002 and 2004 new rules were issued on judgment procedures and the model for preparing operational audit reports. In 2005, rules were issued for the operation of the Project to Combat Fraud and Corruption, prepared based on the visit to the Canadian OAG in 2004.

Finally, regarding to preparation of manuals, the highlight was the approval by the TCU, in 2000, of the Operational Auditing Manual, based on techniques learned during the visits to the NAO in the United Kingdom. In 2001 two more documents were prepared and approved by the TCU referring to operational auditing: the Logical Framework Technique and RACI (responsible, accountable, consulted and informed) Technique. Finally, in 2002 three further documents were issued, covering oversight and auditing techniques: Stakeholder Analysis, SWOT (strengths, weaknesses, opportunities and threats) Analysis and Risk Verification Matrix. The last of these was greatly influenced by the technical visit to Canada's OAG in 2001.

Regarding the variety of the mechanisms for codifying knowledge, this can be considered reasonable. The reports have little influence over variety, mainly because of the requirement to prepare a similar report of activities for each visit, and because of the repetition or organizations visited. Further on the matter of rules, although there were few internal rules issued in the period, their content was quite diversified, dealing with the organizational structure, judgment system and form of preparing reports. Concerning manuals, there was also greater diversity, covering many themes and formats. Finally, a significant level of interaction among the codification processes was observed, mainly because the visit reports were utilized as a primary source for preparing rules and manuals.

Regarding the processes of socializing knowledge, the following were identified: training courses, internal seminars and publication of documents. The most significant focus 
of the training efforts was dissemination of operational auditing. Besides holding periodical courses, starting in 1999 the operational auditing subject was introduced in the analyst training course given to new external control staff of the TCU. Further related to dissemination of operational auditing, a great number of training sessions and presentations given in other entities were identified, the highlight being the courses offered within various state audit tribunals and in counterpart organizations in countries like Cuba and China. Regarding the other themes of the technical visits, there were specific training sessions on application of the risk matrix technique in 2002 and 2003, and on auditing techniques, with focus on environmental auditing, in 2004.

Internal seminars stood out as the most common mechanism used to spread knowledge to the Tribunal's technical staff. However, just as for the training sessions, there was a strong focus on the theme of operational auditing. Various workshops, cycles of presentations and thematic meetings during the period studied were identified. The standouts were the realization in 2001 of a five-day seminar on that theme in the Rio de Janeiro External Control Secretariat and a workshop called "The Experiences in Governmental Control: Canada and the United Kingdom". Concerning the other themes, in 2004 there was a seminar entitled "Incorporating New Dimensions in Evaluating Government Programs", focused on environmental and information technology audits. In 2005 there was a seminar called "Modernization and Improvement of the External Control Activity", with the aim of disclosing accounting and financial auditing and oversight techniques, focused on the public debt.

The publication of documents was strongly influenced by the disclosure of the reports and manuals developed. Among these were the publication in 2000 of a presentation on the performance of government oversight entities and results indicators at the $10^{\text {th }}$ General Assembly of the Organization of Supreme Audit Institutions of Latin America and the Caribbean (OLACEFS) and, in 2002 and 2003, the publication of a series called Executive Summary, conceived to disclose in summarized form information on the main results of the audits of social programs carried out by the TCU. Another point worth mentioning is that with the creation of the intranet sites of the TCUs various secretariats, the reports on the technical visits were disseminated and remain available to interested people. Also of note is the existence of a daily newsletter called Informativo União, which publishes notices of the Tribunal's main activities, summaries of presentations and reports of study trips.

Regarding the variety of these mechanisms, there was a distinct concentration in training sessions and seminars on operational auditing and no record on themes that stood out in the technical visits, such as the case of oversight methods to fight corruption. Nevertheless, the publication of documents had a big impact on the socialization of knowledge, covering the majority of the themes of the technical visits, so that the variety of these mechanisms can be considered ample.. There was a strong interaction among socialization mechanisms and also among the mechanisms for codification of knowledge, since the publication of documents was used as a channel for disclosure before and after the internal training events and seminars, as well as for the approval of manuals and rules on external control activities.

\subsection{Institutionalization}

In this topic is described the influence of the learning attained by technical visits on the institutionalization of external control practices within the TCU. To analyze the institutionalization process the variables Links, Program and Resources / Structure proposed by Esman and Blaise (1966) were used. 
The exam of documents and content of the interviews showed that the TCU maintained stable links with its counterparts in other countries. Based on the quantification of the citations, carried out with the help of the Atlas.TI. software, strongest ties with the control and auditing entities of the United Kingdom, mainly with the National Audit Office and Audit Commission (29 citations), the United States General Accounting Office/Government Accountability Office (11) and Canadian Office of the Auditor General (10) were identified. The predominance of citations referring to the NAO was mainly due to the signing of technical cooperation agreements between Brazil and the United Kingdom.

Concerning links with international control associations, the standouts were those with the International Organization of Supreme Audit Institutions (INTOSAI) and the Organization of Supreme Audit Institutions of Latin America and the Caribbean (OLACEFS). In 2006, people from the TCU took part in committees on auditing rules, public debt, information technology auditing and the working groups on privatization, environmental auditing and program evaluation.

The program variable involves the strategies and plans developed by the organization. For the effect of this study, only the strategies and plans of the TCU in which we identified direct relations with the technical visits conducted in the period studied were included. The exam of documents and interviews shown few references to this variable. However, the references to changes in the Tribunal's Strategic Map were extremely relevant. Besides explaining its mission, the Strategic Map defines the organization's objectives in different areas, grouped into four categories: a) Outputs; b) Internal Processes; c) People and Innovation; and d) Budget and Logistics.

The main evidence of connections between changes in the TCU Strategic Map and technical visits are in the following categories: outputs and internal processes. About outputs the TCU's central objective is "to be known for its contribution to combating corruption, diversion, waste and fraud and improving public administration." The presence is evident of two themes related to the technical visits: combating fraud and corruption and operational auditing, as means to improve government performance.

Analysis of the resources / structure variable sought to identify the human, financial and equipment resources allocated to or used by the TCU related to technical visits carried out or to be undertaken. The highlight was the signing of the technical cooperation agreement between Brazil and the United Kingdom for the development of operational auditing, with initial period of three years (1998-2000), which was then extended for an additional four years. The forecast spending was around $£ 500,000$ by the United Kingdom and $£ 622,000$ by Brazil, corresponding in the latter case to payment of employees of the TCU responsible for administering and executing activities related to the agreement. The implementation of this agreement thus was responsible for allocation of a significant amount of human and financial resources over the period from 1998 to 2004, specifically to develop operational auditing techniques.

In turn, technical visits made in 2004 , which were part of a corporate project named Support for Modernization of the TCU, had financial support from the Inter-American Development Bank (IDB). The TCU received roughly US\$5 million to pay for various projects, among them the one in question.

Another highlight was the changes in the Tribunal's organizational structure related to subjects covered in technical visits. The main ones were the creation of the Secretariat of Oversight and Evaluation of Government Programs in 2000, which was responsible for developing operational auditing technique, and transform the Coordination Office of 
Oversight into the Adjunct Secretariat of Oversight, which was given authority to manage the development and implementation of auditing methodologies and techniques.

\subsection{Isomorphism}

To analyze isomorphism, the typology presented by DiMaggio and Powel (1991) was followed. Normative isomorphism, for which there were three citations, represents identification of the realization of technical visits by the influence of international control organizations, such as INTOSAI and OLACEFS. The theme of these visits was advanced auditing practices, covering subjects that were strongly recommended by these organizations, such as environmental auditing and information technology auditing. It is worth highlighting that the Tribunal made technical visits with the aim of improving its actions in relation to these themes and that in 2006, the TCU assumed a position of leadership in INTOSAI and OLACEFS in relation to environmental auditing, becoming a benchmark for various counterpart entities in other countries and for state audit tribunals in Brazil.

Mimetic isomorphism, which represents the arguments that identify the similarities between the techniques applied within the TCU and those of the peer organizations visited, was the code with the highest number of citations (12). In the case of operational auditing, the United Kingdom was benchmark to affirm that this technique is an indispensable activity within audit and control entities. However, there were constant indications of the need for adaptation of the techniques imported from other entities abroad to overall Brazilian reality and that of the TCU in particular. Further in relation to mimetic isomorphism, the form of disclosing the audit reports attracted much comment as one of the similarities identified with the United Kingdom. The TCU was not concerned about the visual part of these reports. The $\mathrm{NAO}$, on the other hand, presented its reports very stylishly, with images and colors so as to attract the interest of the external public. By recommendation of the team that visited the UK in 2002, the TCU started to adopt a report style similar to that of the NAO.

Coercive isomorphism, despite having few citations (two), deserves mention because it refers to a Brazilian constitutional command, contained in Article 70, regarding operational auditing as falling under the competence of the TCU. The presence of this authority by delegation of the Federal Constitution was a strong source of legitimacy for the technical visits focusing on learning more about operational auditing, confirming the importance of the coercive mechanism in Brazilian society, as indicated by Machado-da-Silva et al. (2003).

\subsection{Discussion of the Results}

The technical visits made by managers and technical staff of the TCU to its counterpart entities in other countries consisted essentially of the search for information on the organizational environment, intending to minimize the uncertainty and environmental pressures, confirming the ideas discussed by Machado-da-Silva and Gonçalves (1998). The acquisition of knowledge occurred at an individual level, and the other learning processes studied were responsible for conversion of the knowledge, enabling its transfer from the individual to the group and organizational levels, confirming the affirmation of Pantoja and Borges-Andrade (2004).

Observing the dynamic of learning processes related to the desired knowledge from technical visits, especially regarding the transfer of knowledge from the individual to the organizational level, we found a possible connection between the model for analyzinglearning processes proposed by Figueiredo (2003) and that put forward by Zietsma et al. (2002), who examine the transfer of learning from the individual to the group and organizational levels 
(feedforward) and the effect of institutionalization of knowledge on the activities of the organization, group and individual (feedback).

In light of the characteristics of the external knowledge acquisition processes proposed by Figueiredo (2003), specifically with respect to the technical visits studied, we identified similarities with the process of obtaining information (dubbed "attending") in the model of Zietsma et al. (2002). In turn, the processes of codification and socialization observed operated as a means of integration and institutionalization, as contained in the model of Zietsma et al. (2002), which places them at the organizational level. According to this model, these processes are responsible for the sedimentation of changes in the procedures, routines, rules and structures, in a feedback process that goes from the organizational back to the individual level.

Based on an analysis of the variables related to the learning process and the institutionalization phenomenon, it can be concluded that the technical visits did contribute to the acquisition of external knowledge, the direct products being the application within the TCU of oversight techniques in environmental and information technology areas, risk analysis technique and particularly the importation of the operational auditing activity.

A strong influence of the technical visits on the occurrence of mimetic isomorphism, specifically regarding knowledge about operational auditing was observed. There were many similarities between actions of the TCU and the NAO. The latter organization was the main benchmark for the TCU on that matter, and these two entities have a solid and lasting relationship. The clear motivation for the visits to the NAO was operational auditing, and there was even follow-up evaluation by staff from the NAO of the actions of the TCU, supporting this inference.

For other lines of knowledge, a direct link between the process of acquiring external knowledge and the mimetic phenomenon was not identified. No relevant evidence of normative and coercive isomorphism was not found, concluding that these phenomena were absent in the other areas of knowledge that prompted the technical visits.

A factor that perhaps minimized the evidence of mimetic isomorphism was the explicit awareness of the need to adapt techniques imported from counterpart entities, mainly because of the peculiarities of the TCUs attributions and the social and cultural context of which it is part. It should be pointed out that adaptation does not remove the mimetic character from the process, but it does act to attenuate the evidence of this.

We also identified the existence of a relation between the links and the learning processes observed. The signing of the technical cooperation agreement between Brazil and the United Kingdom provided the TCU with greater facility to obtain knowledge on operational auditing. Besides this, the more solid and lasting ties between the TCU and its UK counterpart stimulated the investment of resources and the modification of the Tribunal's structure, which resulted in a greater quantity and quality of the other processes of codifying and socializing knowledge on operational auditing.

The finding, from analysis of the program variable, of the presence of various themes of the technical visits on the TCU's Strategic Map is strong evidence of the incorporation of these ideas in the organization. Although a more detailed analysis of the institutionalization of each of the activities that were the object of the visits is necessary to reach fuller conclusions, we can state that these visits did stimulate the introduction of new external control practices within the TCU. Freitas and Guimarães (2007) have already studied the institutionalization of one of these activities - operational auditing - and concluded that this practice has become fully institutionalized. 
The results thus suggest that the technical visits, allied with the processes of conversion of the knowledge acquired, had an important role in the institutionalization of the external control processes in the TCU. It is possible that this learning process provides a greater flow of resources for effective incorporation of the activity or methodology learned. These resources, in turn, enabled the forging of more solid ties with other oversight organizations, providing new learning opportunities, which confirms the existence of the feedforward and feedback macro-processes contained in the model of Zietsma et al.(2002).

\section{CONCLUSIONS}

The interaction between the technical visits, as a process of acquiring knowledge, and the other processes of codification and socialization, especially the preparation of reports, publication of technical documents and holding of training sessions, enabled the transfer of learning from the individual to the organizational level.

Based on the analysis of the characteristics of the technical visits studied, we identified similarities between the learning processes presented by Figueiredo (2003) and the model of Zietsma et al. (2002), principally with respect to the steps of acquiring external knowledge and obtaining information. In turn, the codification and socialization processes observed functioned as a means for the integration and institutionalization steps contained in the model of Zietsma et al. (2002), which are situated at the organizational level. These processes appeared to be responsible for the sedimentation of changes in the procedures, routines, rules and structures, in a feedback process from the organizational to the individual level.

The results suggest the existence of a strong influence of the visits on the occurrence of mimetic isomorphism, specifically involving knowledge related to operational auditing. We identified various similarities between the actions of the TCU and the United Kingdom's NAO, which was the main benchmark for this knowledge. Although we identified evidence of normative and coercive isomorphism, we did not consider this sufficient to characterize a mixed conduct. The mimetic characteristics were much more important than the other isomorphic types.

Regarding the variables related to institutionalization, we identified a direct relationship between the more solid and permanent ties and the institutionalization of practices. As stated, the most important link was between the TCU and the NAO. This stimulated the investment of resources and the alteration of the Tribunal's structure, resulting in a greater quantity and quality of the other processes of codifying and socializing knowledge. We also identified a relation between the technical visits and the program variable, shown by the inclusion of the practices that were the object of the visits in the Tribunal's Strategic Map.

In closing, considering the variables used in this study, we can state that the realization of the technical visits, allied with the processes of converting the knowledge acquired, played an important role in the institutionalization of the TCU's external control practices, in an isomorphic context.

\section{REFERENCES}

ARGYRIS, Chris and SCHÖN, Donald D. Organizational Learning II: Theory, Method and Practice. Massachusetts: Addison-Wesley Publishing Company, 1996.

BASTOS, Antônio Virgilio Bittencourt, GONDIN, Sônia Maria G. and LOIOLA, Elizabeth. Aprendizagem Organizacional versus Organizações que aprendem: características e 
desafios que cercam essas duas abordagens. Revista de Administração. São Paulo, V.39, n.3, pp.220-230, 2004.

CABRAL, A. C. A. Aprendizagem organizacional como estratégia de competitividade: Uma revisão da literatura. In: S.B. RODRIGUES; M. P. CUNHA (orgs.) Estudos organizacionais: novas perspectivas na administração de empresas: uma coletânea lusobrasileira. São Paulo: Iglu, 2000, pp. 227-247.

CHOO, Chun Wei. A Organização do Conhecimento: como as organizações usam a informação para criar significado, construir conhecimento e tomar decisões. São Paulo: Editora Senac São Paulo, 2003.

CROSSAN, Mary M.; LANE, Henry W.; WHITE, Roderick E. An Organizational Learning Framework: From Intuition to Institution. Academy of Management Review. Vol. 24, n.3, pp. 522-537, 1999.

DIMAGGIO, Paul J.; POWELL, Walter W. The Iron Cage Revisited: Institutional Isomorphism and Collective Rationality in Organizational Fields. In: POWELL, Walter W.; DIMAGGIO, Paul J. The New Institutionalism in Organizational Analysis. Chicago: The University of Chicago Press, 1991. pp. 63-82.

DODGSON, M. Organizational Learning: a review of some literatures. In: Organizations Studies. [s.1. : s.n.]. v. 14, n. 3, 1993, pp. 375-394

DOVING, Erik. The image of Man: Organizational action, competence and learning. London: Sage, 1996, pp. 185-199.

EASTERBY-SMITH, Mark and ARAUJO, Luis. Aprendizagem Organizacional: Oportunidades e Debates. In: ESTERBY-SMITH, M., BURGYONE, J and ARAUJO, L. (Coords). Aprendizagem Organizacional e Organização de Aprendizagem: Desenvolvimento na Teoria e na Prática. São Paulo: Atlas, 2001.

ESMAN, M.J. and BLAISE, H.C. Institution Building Research: The Guiding Concepts. Pittsburgh: Inter-University Research Program in Institution Building, 1966.

FIGUEIREDO, Paulo C. Negreiros de. Aprendizagem tecnológica e performance competitiva. Rio de Janeiro: Editora FGV, 2003.

FIOL, Marlene C. and LYLES, Marjorie A. Organizational Learning. Academy of Management. The Academy of Management Review, v. 10 n. 4, pp. 803-813,1985.

FOUNTAIN, Jane E. Building the Virtual State: Information Technology and Institutional Change. Washington: Brookings Institution Press, 2001.

FREITAS, Carlos Alberto Sampaio de and GUIMARÃES, Tomás de Aquino. Isomorphism, Institutionalization and Legitimacy: Operational Auditing at the Court of Auditors. Brazilian Administration Review, v. 4, n. 1, art. 3, pp. 35-50, Jan./April 2007.

GINSBERG, A.; BUCHHOLTZ, A. Converting to for-profit status: corporate responsiveness to radical change. Academy of Management Jour, v. 33, pp. 445-477, 1990.

GUIMARÃES, Tomás de Aquino. Aprendizagem e Cultura em Organizações: Estudo de caso em organização militar. São Paulo, Revista de Administração da Universidade de São Paulo - RAUSP, V.39, n.3, July-Aug.-Sept. 2004.

HANNAN, M.T., FREEMAN, J. The Population Ecology of Organizations. American Journal of Sociology, v. 82, n. 5, pp. 929-964, 1977. 
JEPPERSON, R. Institutions, institutional effects and institutionalism. In: POWELL, W.; DIMAGGIO, P. (eds.) The new institutionalism in organizational analysis. Chigaco: University of Chigaco Press, 1991. pp.143-63.

MACHADO-DA-SILVA, Clóvis L; GONÇALVES, Sandro A. Nota Técnica: A Teoria Institucional. In: CLEGG, Stewart; HARDY, Cynthia; NORD, Walter R. (Org.) Handbook de Estudos Organizacionais. São Paulo: Atlas, 1998. v. 1, pp. 220-226.

; GUARIDO-FILHO, Edson Ronaldo. A Influência de Valores

Ambientais e Organizacionais sobre a Aprendizagem Organizacional na Indústria Alimentícia Paranaense. Revista de Administração Contemporânea. Curitiba: ANPAD, v.5, n.2, May-Aug., 2001, pp. 33-63.

NASCIMENTO, M. R.;

OLIVEIRA, Patrícia Tendolini. Institucionalização da mudança na sociedade brasileira: o papel do formalismo. In: VIEIRA, Marcelo Milano F.; CARVALHO, Cristina Amélia (Orgs.). Organizações, Instituições e Poder no Brasil. Rio de Janeiro: FGV, 2003. pp. 179-202.

MENDONÇA, J. Ricardo C. de; AMANTINO-DE-ANDRADE, Jackeline. Gerenciamento de Impressões: em busca de legitimidade organizacional. Revista de Administração de Empresas, São Paulo, v. 43, n. 1, pp. 36-48, Jan./Mar. 2003.

MEYER, John W.; BOLI, John; THOMAS, George M. Ontology and Rationalization in the Western Cultural Account. In: SCOTT, W. Richard; MEYER, John. (Org.) Institutional Environments and Organizations: Structural Complexity and Individualism. Thousand Oaks: Sage, 1994.

NONAKA, Ikujiro and TAKEUCHI, Hirotaka. Criação de Conhecimento na Empresa: como as empresas japonesas geram a dinâmica da inovação. Rio de Janeiro: Campus, 1997.

PANTOJA, Maria Julia and BORGES-ANDRADE, Jairo Eduardo. Contribuições teóricas e metodológicas da abordagem multinível para o estudo da aprendizagem e sua transferência nas organizações. in Revista de Administração Contemporânea, v.8, n. 4, Oct./Dec. 2004, pp. 115-138.

RICHARDSON, Roberto Jarry et al. Pesquisa Social. Métodos e Técnicas. São Paulo: Atlas, 1999.

SCOTT, W. R .; MEYER, John. The Organization of Societal Sectors. In: MEYER, John;

W.; SCOTT, W. R. Organizational Environments: Ritual and Rationality. Newbury Park: Sage, 1992. pp. 129-153.

Prentice Hall, 1998.

Organizations, rational, natural and open systems. 4th ed., New Jersey: Institutions and Organizations. Thousand Oaks: Sage Publications. 2nd ed. 2001.

SELZNICK, P. A liderança na administração: uma interpretação sociológica. Rio de Janeiro: Fundação Getúlio Vargas. Serv. de publicações, 1971.

TOLBERT, P.S.; ZUCKER, L.G. A Institucionalização da Teoria Institucional. In: CLEGG, S.;HARDY, C.; NORD, W. (Org.) CALDAS, M.; FACHIN, R.; FISCHER, T. (Org. brasileiros) Handbook de Estudos Organizacionais: modelos de análise e novas questões em estudos organizacionais. Vol. 1. São Paulo: Atlas, 1999. 
VIEIRA, Marcelo Milano Falcão. Por uma boa pesquisa (qualitativa) em administração. In: VIEIRA, Marcelo Milano Falcão and ZOUAIN, Deborah Moraes. Pesquisa Qualitativa em Administração. Rio de Janeiro: Editora FGV, 2004.

YIN, Robert K. Estudo de Caso: planejamento e Métodos. Porto Alegre, Bookman, 2001.

ZIETSMA, Charlene; WINN, Monika; BRANZEI, Oana and VERTINSKY, Ilan. The War of the Woods: Facilitators and Impediments of Organizational Learning Processes. British Journal of Management, vol. 13, S61-S74, 2002. 